\title{
13. Listening to Cavell
}

\section{KAY YOUNG}

We hurried to get the front row seats. Even to nineteen-year-olds, it was clear that what was happening in that lecture hall-fittingly, it was Emerson 105-was worth waking up for, worth pushing to the front for, as if we couldn't get close enough. And what we couldn't get close enough to was Stanley Cavell lecturing on Western philosophy-a course humbly called "Hum 5" ("Humanities 5: Introduction to Western Philosophy")-looking back, now forty years later, I can say it was probably the most significant intellectual experience of my life. Cavell's commanding presence-that big head, fixed gaze, and seriousness of purpose-made his entrance onto the dais, raincoat and brief case in hand, an anticipated event. But what dawns on me now is that it wasn't so much Cavell's presence or even what he said that made us feel a shared sense of urgency, but rather how he said it, how he performed this urgency that made us feel like we were somewhere else-a world viewed through Cavell's mind.

When Cavell spoke, it felt like he was turning his mind inside out, not so that we could see what he meant (I think more often than not we couldn't see what he meant)-but so that we could hear how he meant-the sounded feeling of meaning. Cavell's voice, that startling philosophic voice in his writing was more pronounced, more resonant, more dramatic in speech-because he performed his philosophic voice, pronouncing, resonating, playing his speech and his thinking like a great vocal instrument. Cavell performed language, played language as he played with language, as if speech was a musical instrument or as if thinking out loud was singing. We knew nothing of his past as a musician, or as the son of a pianist with perfect pitch, or as a young man who studied and aspired to compose music. What we knew was that at nineteen we felt hungry, that listening to him made us know our hunger, because he sounded that hunger-call it the feeling of having a mind. Philosophy, "doing philosophy," in the company of Cavell was mental food-it woke us to our intellectual cra- 
vings because we heard his. Cavell embodied what it meant to take one's mind seriously by giving voice to where his mind traveled when he listened with that unparalleled attention of his to the language of other philosophers or Shakespeare or Hollywood films-a listening attention we yearn for and maybe also fear?

"Must We Mean What We Say?" is not "Must We Mean What We Write?” A matter of saying it-is Cavell's matter. As much as writing it matters, that comes second to what it means to speak it. Cavell, like Wittgenstein, returns time and again to why it is and how it is and maybe most essentially when it is that the world and the word come together in speech and when they fail to do so, as in-"[W]e forget that we learn language and learn the world together, that they become elaborated and distorted together, and in the same places." 1

Two passages from “Must We Mean What We Say?”:

The philosopher, understandably, often takes the isolated man bent silently over a book as his model for what using language is. But the primary fact of natural language is that it is something spoken, spoken together. Talking together is acting together, not making motions and noises at one another, nor transferring unspeakable messages or essences from inside of one closed chamber to the inside of another. The difficulties of talking together are, rather, real ones: the activities we engage in by talking are intricate and intricately related to one another. ${ }^{2}$

And

It sometimes happens that we know everything there is to know about a situation-what all the words in question mean, what all the relevant facts are; and everything is in front of our eyes. And yet we feel we don't know something, don't understand something. In this situation, the question, 'What is X?' is very puzzling, in exactly the way philosophy is very puzzling. We feel we want to ask the question and yet we feel we already have the answer [...]. Socrates

1. Cavell, Must We Mean What We Say?: A Book of Essays (Cambridge: Cambridge University Press, 2002), 19.

2. Ibid., 34 . 
says that in such a situation we need to remind ourselves of something. So does the philosopher who proceeds from ordinary language: we need to remind ourselves of what we should say when. ${ }^{3}$

Here are a few of the things Cavell does in these passages: change the visual portrait of the philosopher silently reading, bent over a book, as the model of what it means to "do" philosophy to an aural portrait of speaking together. He names "speaking together" "acting together" and he acknowledges the difficulties of such activities, most especially in their relation to each other. He goes on to speak about knowledge as bound to context, as in-"It sometimes happens that we know everything there is to know about a situation" and in so doing underscores the mystery of what it means "to know," which underscores the paradox of the human condition-what it means to know is also what it means not to know. He situates that feeling around the ocular - "everything is in front of our eyes" and "yet we feel we don't know something, don't understand something." Like Shakespeare, Cavell will make "ocular proof" something that which confounds as much as it explains, and so his reading of Othello in The Claim of Reason. Cavell brings in the verb "to feel" as the sense we have about this knowing-not knowing state, understanding-not understanding. It will be his attention to the non-visual, feeling of a word, feeling of knowing not-knowing, what he will call "the felt quality" of a thing that will come to define much of his work. And he concludes by drawing our attention to what he has been doing all along, which is the groundwork of ordinary language philosophy, the recognition of the contextual scene of language-what we should say when. "What we should say when" holds ordinary language philosophy's reply to metaphysics and to skepticism, and so Cavell's essay "Knowing and Acknowledging."

"Philosophers who shun the autobiographical must find another route to philosophical authority... (logic, as Kant says, is such a route)."4 The route that aspires to metaphysical truth along the path of if $p \sim q$ creates a voiceless "we" in the search for necessity and universality-where the particular and the meaning of the particular fall away or get erased clean. For Cavell, it is in our limits-that which defines the 
very particular marks and tones of our voices and our stories-where philosophy's other route to authority lies. He connects this proposal to the directives of the two ordinary language philosophers who lead Cavell to his intellectual voice, J. L. Austin at Oxford and later Wittgenstein, whose work he comes to realize "demand a systematic engagement with the autobiographical."5 Wittgenstein's motto-“"What we do is lead words back from their metaphysical to their everyday use" and Austin's "to ask ourselves what we say when (that is, in varying contexts)"-bring us back to the everydayness of language and our lives, or language in the context of life. Reflecting back on the writing of "Must We Mean What We Say" from the vantage point of the 1994 lectures that compose $A$ Pitch of Philosophy (some thirty-seven years later), Cavell writes:

I was unprepared to claim that the interest in the new philosophy lay precisely in the necessity and openness of its arrogance and its autobiographicality, that these are not personal but structural features of the necessity to say what we say, that in thus laying their bodies on the philosophical line, and living to tell their tale, the likes of Wittgenstein and Austin must be tapping a dimension of philosophy as such [...]. The autobiographical dimension of philosophy is internal to the claim that philosophy speaks for the human, for all; that is its necessary arrogance. The philosophical dimension of autobiography is that the human representative, say, imitative, that each life is exemplary of all, a parable of each; that is humanity's commonness, which is internal to its endless denials of commonness. 6

I take Cavell's coming to the autobiographical as a necessary feature of ordinary language philosophy and more generally as a philosophic line that makes possible its speaking for the human in response to 1) the erasure of voice of a metaphysics grounded in a priori logic and 2) in the necessity of voice in an ordinary language philosophy grounded in context. To acknowledge our limits-that to be human is to be grounded always in context-means to make autobiography a means to do philo- 
sophy, where "each life is exemplary of all, a parable of each." For those of us who think about narrative, we say, "Yes, of course." But for philosophers, this claim required, maybe still requires, defense-“Must We Mean What We Say?" is the defense of his teacher Austin that began Cavell's career in philosophy. That posture and sound of defense come to be defining features of Cavell's career. Speaking of Austin and Wittgenstein, he admits, "I was unprepared-and not just intellectually-for the intensity of hostility their work inspired."7 Beginning in defense of his teacher, Cavell finds his intellectual voice, a voice which will come to adopt tones of self-defense and of rightful inheritance, of hurt and of expansion, of humility and of grandiosity. They are shared tones Cavell comes to trace in other writers of Western philosophy. With that tracing comes a hearing of philosophy's autobiographical voice. Here's how he begins the Harvard-Jerusalem lectures that became A Pitch of Philosophy:

The arrogance of philosophy is not one of its best kept secrets. It forever toys with worlds, and when it discovers humble human pride, like Kant's in proving the necessary limitation of human knowledge, of Nietzsche's in interpreting our resentments, it finds itself exorbitantly superb. A formative idea in planning these lectures was to pose the question whether, or how, philosophy's arrogance is linked to its ambivalence toward the autobiographical, as if something internal to the importance of philosophy tempts it to self-importance. Arrogance and autobiography are clearly enough linked in such an outburst of Thoreau's in Walden as "I brag for humanity," and of Nietzsche's in Ecce Homo as "I have [...] given mankind the greatest gift that has ever been given it [...]. I propose here to talk about philosophy in connection with something I call the voice, by which I mean to talk at once about the tone of philosophy and my right to take that tone and to conduct my talking, to some unspecified extent, anecdotally, which is more or less to say, autobiographically. ${ }^{8}$

"Arrogance," "autobiography," "ambivalence"-why these three when thinking about philosophy-how might they be linked? Perhaps each offers a mode or impulse for 
voice, for imagining one has something to say. Perhaps, when voiced, each conjures the other when heard-as in-a right to claim and a tempering of that right, that claim; a necessary and liberating turn to "I" for its words and world and for the denial of those words and world; a space for imagining meaning-making and a space for imagining our limit to do so-

Cavell's "right to take that tone"-his claiming of that right-puts us in mind of his teacher Austin who says in "Lecture X" of the William James Lectures of 1955, reprinted in 1962 as How To Do Things With Words, "[T]o say something is to do something."9 To which I add: And how you say something is to do something, too. For me, what Cavell's right to tone does is to represent our shared "right to take that tone"that that 'right' and that 'tone' means something about what it means to be human.

To read Cavell "take that tone" in writing and to hear Cavell "take that tone" in speaking performs a belief in "other minds" and joins us together in a democracy of minds: Cavell's "right to take that tone" is our right, too. Cavell's hearing of autobiography in philosophy, "how I think and feel when," awakens us each to "how I think and feel when." It's not only philosophy that has a problem with the "I"-the academy resists such enunciations of "I." We are taught not to write from the position of "I," as if "that tone" will negate what makes for a strong argument-necessity and universality-and so, too, must fall short of "the truth." What Cavell's voice does is to make a claim for voice, for our voices, to help us grow more confident in our claim to voice and what we each have to say-which is that we each have something to say, something worth listening to.

Who are the teachers who help us claim voice? I believe they are the great teachers. They are the ones who help us each imagine that we have the "right" to think, to feel, and to say "I have a mind of my own-to think and to feel and to say. Such teaching feels urgent, rare, unforgettable, and freeing. Cavell was that teacher to me, to many of us.

I close with memories of Cavell teaching by way of Cavell's great teachers-J. L. Austin and Ernst Bloch. In A Pitch of Philosophy Cavell remembers what it felt like to be Bloch's student:

9. J. L. Austin, How To Do Things With Words (Cambridge. MA: Harvard University Press, 1962), 120. 
I close with an experience that assured me of an equivalent perfect pitch, of evidence of a world I think, at the limit of the world I had conversed with-an experience of music [...]. The moment came in Ernst Bloch's music theory class [...]. I was a second-year student at Berkeley. He was in his mid-sixties, my age now, and would sometimes tell stories of Paris around the turn of the century when he was a music student roughly my age as I was listening to him then. Sometimes he was moved by a memory to give a demonstration of what conducting essentially consisted in, asking what communication is, or what constitutes a cue; or he would cover both long walls of staved-lined blackboards with different dispositions of a C-major triad to warn against believing in simple or academic definitions of harmonic correctness or of proper voice-leading; or he would interrupt himself to read an excerpt from Plato, or from Confucius, or-a recent discovery of his-from Stanislavsky; or he might move to the piano to play a passage from a Schumann string quartet referred to by an anecdote from the history of Robert and Clara Schumann related in someone's letters; and all in all he bespoke a world of aspiration so vivid, a life of dedication so extensive and so constant-as if a wish were being granted me every moment-that I would at the end of a class sometimes find myself having trouble breathing, and I formed the habit of walking immediately after each of its sessions into adjacent hills for an hour or so of solitude, as if I had become too consecrated to touch. Well, well, what do you expect of the effects of the spell of an old master on a young man? [... T] he young wild with muteness, feeling for the first time intelligible, but to a world he at the time surmises not quite to be his [...]. It will take some years to discover another, but I knew from that time inescapably-not always hopefully-of the promise of some such existence." 10

I read that and say, "Yes. Your experience of Bloch was ours of you." "[H]e bespoke a world of aspiration so vivid, a life of dedication so extensive and so constant-as if a wish were being granted me every moment-..." "It was like that for us with you."

10. Cavell, A Pitch of Philosophy, 48-49. 
Cavell reflects on what it meant to be taught by Austin in his essay "Austin at Criticism" of 1965:

Seven published papers are not many, and those who care about Austin's work will have felt an unfairness in his early death, a sense that he should have had more time. But I think it is wrong to say his work remains incomplete. He once said to me, and doubtless to others: "I had to decide early on whether I was going to write books or to teach people how to do philosophy usefully." Why he found this choice necessary may not be clear. But it is as clear as a clear Berkeley day that he was above all a teacher, as is shown not merely in any such choice, but in everything he wrote and (in my hearing) spoke with its didactic directions for profitable study, its list of exercises, its liking for sound preparation and its disapproval of sloppy work and lazy efforts. In example and precept his work is complete, in a measure hard to imagine matched. I do not see that it is anywhere being followed with the completeness it describes and exemplifies. There must be, if this is so, various reasons for it. And it would be something of an irony if it turned out Wittgenstein's manner were easier to imitate than Austin's; in its way, something of a triumph for the implacable professor. ${ }^{11}$

Austin's choice was not Cavell's, or at least Cavell didn't find the choice between teaching and writing a necessary one to make. Both were necessary. Both were urgent. What was "implacable" about Cavell was his need to say-"a matter of saying it." Cavell's teaching was not like Austin's-no didactic directions for profitable study, no list of exercises, no judgments about sound preparation or sloppy work and lazy efforts. Cavell was the student who carried forward Austin's training and directive-not in imitation, but in practice. Austin concludes the William James lectures with words about his own teaching and what remained to be done with it:

I have as usual failed to leave enough time to say why what I have said is interesting [...]. I have purposely not embroiled the general theory [ordinary lan- 
guage philosophy] with philosophical problems (some of which are complex enough to merit their celebrity); this should not be taken to mean that I am unaware of them. Of course, this is bound to be a little boring and dry to listen to and digest; not nearly so much as to think and write. Moreover I leave it to my readers the real fun of applying it to philosophy. ${ }^{12}$

How to do things with Austin's words is one way to define the contours of Cavell's work. Cavell was that "reader" who made a life of "the real fun of applying it to philosophy." Schooled on Austin's rigorous attention to "words when" and Ernst Bloch's intellectual soaring, what Cavell was not was "a little boring and dry to listen to and digest," but instead rigorous and soaring. "I have a bee in my bonnet," he might begin. And so the buzzing around would begin for all us as we traveled from sound to sound, the flowering of one idea to the next. Or maybe he would call it a philosophic mood, or maybe name it "the problem of other minds," or "Emersonian perfectionism," or "the melodrama of the unknown woman," or maybe he would draw attention to Shakespeare's sounding of Mamillius's sad tale of winter in his mother Hermione's ear, or give voice to Milton's definition of marriage as a "meet and happy conversation," en route to listening to the talking of a Hollywood comedy of remarriage in its embodiment of that conversation.

I hear his voice still-the fullness and depth, the distinct cadences, the acceleration as he moved closer to what he wanted to say, the slowing pauses as he added parentheticals that interrupted the idea's flow with examples begun with the word "say" or "which is to say" or with questions that made even more particular the direction of the idea's flow revealing a connecting link to circle back to where we had left off, the silences that brought us together in moments of shared recognition or reflection. How his voice traveled out of Emerson 105, one flight up, to the room where the nineteen-year-olds of the front row met each week with a remarkable philosophy graduate student, Steve Phillips, to discuss what was happening in our minds-Lisa Feurzig, David Kellogg, Paul Bayard, Steve Irwin, Dan Silver-and the one to whom I gave the epithet "smartest boy in class"-Jeff Saver-that boy who I still see in my mind's eye from the steps of Memorial Church walking through the Yard carrying a 
copy of Wittgenstein's Philosophical Investigations, that boy whose aliveness in Hum 5 I shared in and cherished, more than I can say. Hum 5 was not just the most significant intellectual experience of my life-four years later, after sitting together to hear Cavell and to hear one another's minds come alive in response to him and to one another, Jeff Saver and I married. And four years later, Cathleen and Stanley Cavell were there, at our wedding, to share in what happened, what continues to happen because of Hum 5 and listening to Stanley Cavell. 